TP Periodica Polytechnica

Social and Management

Sciences

23(2), pp. 142-150, 2015

DOI: $10.3311 /$ PPso. 7620

Creative Commons Attribution (i)

RESEARCH ARTICLE

\section{The Impact of Big Five Personality Traits and Positive Psychological Strengths towards Job Satisfaction: a Review}

\author{
Chandrasekar Therasa ${ }^{1}$, Chidambaram Vijayabanu ${ }^{1 *}$
}

Received 14 July 2014; accepted after revision 02 December 2014

\begin{abstract}
Human resource can be a dynamic asset or a debilitating liability depending upon how well it is harnessed. Many progressive organizations around the world have begun to internalize this reality and keeping the human resource satisfied is considered one of the key factors for the success of any organization. Dispositional base of job satisfaction has gained renewed interest since job satisfaction is a mixture of beliefs and feelings. With an eye toward research and practice, the current study consolidates various literatures and examines the relationship between Big Five Personality, Positive psychological strengths towards job satisfaction. The study also takes into consideration the demographic impact towards job satisfaction. It provides acumen and a different magnitude for predicting job satisfaction apart from conventional variables like work itself, pay, promotion, supervision, co-workers.
\end{abstract}

\section{Keywords}

Big Five Personality, Positive Psychological strengths, Dispositional base of Job Satisfaction

${ }^{1}$ SASTRA University, Thanjavur

Tamil Nadu, India

${ }^{*}$ Corresponding author, e-mail: vijayabanu@mba.sastra.edu

\section{Introduction}

The inter-relationship between personality factors and job satisfaction has been a periodic study in industrial psychology in the past century (Judge et al., 2002). Job satisfaction is one of the core constructs in management and is the most extensively studied variable in industrial psychology and organization behavior. It is not uncommon to see any research journal on management that does not contain at least one study that is related to job satisfaction (Sarwar and Abugre, 2013), and it has become a worldwide reality in the human behavior studies, that satisfaction and productivity are significantly related.

Employee satisfaction plays a vital role in success of any organization, and banks are no exception. For the bank to emerge as a globally competitive financial entity, satisfied workforce becomes inevitable. The motivated employees are satisfied employees who have greater morale, oneness and promote cohesiveness among the members of the organization (Vijayabanu et al., 2013). Hence to sustain in the competitive environment, it is very much necessary to understand the employee's perception towards the job and to measure the level of satisfaction with various aspects of job satisfaction. Efficient Human Resource management and a highly satisfied workforce not only enhance the performance of the bank, but also boost the entire economy. For the accomplishment of best banking services it is innate to manage the human resource effectively by gauging the job satisfaction level of employees in a periodic basis. The success of an organization (Vijayabanu and Amudha, 2012) depends on the appropriate use of manpower which will be an auxiliary to all other assets.

If they are highly satisfied, they engage themselves progressively and in turn the organization will also develop and reach the pinnacle. A case study has thrown a light which focuses on job satisfaction of banking employees revealed that a win-win environment should be created amidst banking scenario which in turn promotes the economic growth (Ahmed and Uddin 2012). In Service sector, "companies have to increase their customers' satisfaction to keep their competitiveness" (Koltai and Kalló, 2010). Service process performance (Vijayabanu and Amudha, 2012) of the organization should be measured 
continuously to retain the core competency which is possible by understanding the personality aspects also. A Job Satisfaction model proposed by (Agho et al., 1993) concentrated on three dimensions namely environmental, job characteristics, and personality. The result of their research articulated that job satisfaction was strongly influenced by these three dimensions and $57 \%$ of the variance with respect to job satisfaction has been demonstrated by the model proposed by the researchers. Initially the research conducted by them neglected the above said dimensions and the percentage of variance in job satisfaction was $49 \%$. Job Satisfaction can be an abstract function of situational conditions, personality characteristics, and job characteristics which has been defined as a vital element of job satisfaction, and neuroticism also plays a major role (Cohrs et al., 2006). Even though several researchers have concluded that situational factors are powerful predictors of job satisfaction, it is mandatory to study the other aspect because organizational behavior is affected by both situational and dispositional factors. A person's thinking, feeling, behavior is influenced by both personality and situational factors and hence it is essential to give importance to both aspects in predicting recognizable organizational behavior. The personality of the employee is inevitable in determining the level of job satisfaction when he was equipped with job description (Vijayabanu and Therasa, 2014).If an employer understands employee's personalities and their unique abilities then he will motivate the employees to perform their best and in turn, it will enhance individual job satisfaction. To understand and predict the job satisfaction, it is necessary to determine personality characteristics which become necessary to render superior quality of service in banks.

The study has the following objective:

- To study the impact of Big Five Personality traits, positive behavior strengths towards job satisfaction.

The study aims to analyze the importance of Big-Five personality dimensions and positive psychological strengths in predicting the job satisfaction of employees in banking sector.

\section{The role of personality in predicting job satisfaction}

The Five Factor model (FFM) of personality served as one of the flagships for the examination of trait-occupational criteria relationships over the past fifteen years (Salgado, 2005). The FFM of personality provided a new and massive impetus to personality research for different applications in Industrial, Work and Organizational Psychology.

Although numerous studies have been done on identification of antecedents of job satisfaction over the past few years, dispositional sources are given less importance and the association of the Big Five personality on job satisfaction is much less studied (Gelade et al., 2006). A few case studies have also dealt with understanding the importance of job satisfaction and how it is perceived as an influential factor in determining employee loyalty and performance. A case study was developed based on the data collected from employees in an organization regarding job satisfaction and employee engagement (Medlin, 2010). It mainly concentrates on three aspects namely promotional opportunities, maintaining relationships and rewards. The crucial nature of the dispositional approach is that, individuals have a set of stable traits which are inflexible and that significantly influence affective and behavioral aspects of individual in organization setting. Various studies have accepted that the dispositional nature influences job satisfaction of an individual and its correlation with individual differences variables like Positive and negative affectivity (Connolly and Viswesvaran, 2000; Thoresen et al., 2003), core self-evaluations (Dormann et al., 2006; Judge and Bono, 2001; Judge et al., 1998), Big five personality factors (Judge et al., 2002; Tokar and Subich, 1997). There are various literatures in field research case studies which concentrate on various domain areas like personality, Job performance, Loyalty and Engagement. A case study for car sales personnel in Ford-Right Co Ltd, a Ford car dealer in Taiwan (Chen, 2013) revealed that the competence and personality are the most important factors which exhibit positive relationship with job performance and customer loyalty. Therefore gauging job satisfaction level through personality as a factor is a new facet in envisaging Organizational Behavior.

The current study analyzed the impact of Big Five personality Model in predicting Job Contentment is studied from the perspective of the five-factor model of personality.

\section{The Five Factor model of personality}

Many researchers have concluded that traits are responsible for one's personality and it can be organized into a hierarchy (Digman, 1990; Goldberg, 1993; Hampson et al., 1986; Paunonen, 1993). Through factor analysis, five general personality traits are found and placed at the top of the trait hierarchy which has been developed as a Big five model of Personality which has strong valid empirical support (McCrae and Costa, 1996). Research also showed that the Big Five personality model and their facets have a genetic basis (Digman, 1989) and that they are probably inherited (Jang et al., 1996). The five general traits are: extraversion, agreeableness, conscientiousness, neuroticism and openness to experience.

\section{Extraversion}

Extraversion represents the individuals who are high in positive emotions, excitement seeking. Extroverts are more prone to positive emotions and they will be strong in developing interpersonal relationship with others. Extraversion and neuroticism appears to be predictors of burnout (Bakker et al., 2006). Extraversion was significantly related to positive affectivity (Judge and Illies, 2002). It would be cogent to presume that extroverts have higher job satisfaction levels than introverts because of the influence of positive thoughts that acts as a stimulant which 
helps increase their performance and these findings are also supported by (Connolly and Viswesvaran, 2000).

\section{Neuroticism}

Opposite to Extraversion, an individual high in neuroticism is prone to get affected with negative events. They tend to exhibit traits like, fear, anger, depression, easily inclined to stress, not able to control impulses. To predict job dissatisfaction level, neuroticism plays a crucial part (Clark and Watson, 1991; Cropanzo et al., 1993; Tokar and Subich, 1997). A Study by (Tanoff, 1999) in an international organization concluded that neuroticism is a primary factor, in determining job satisfaction. Further, (Connolly and Viswesvaran, 2000) asserted that neuroticism, which is a primary input of negative affectivity badly, influences job satisfaction.

\section{Openness to Experience}

It comprises of traits such as creativity, imaginative, original, willingness to take risks, broad-mindedness, innovativeness, and variety seekers.

A study conducted by (Cohrs et al., 2006) concluded that Openness to experience was associated with higher job satisfaction among mathematics teachers, and their professional qualification also plays a major role in determining the job satisfaction levels. (Schneider, 1999) has highlighted that the association between different personality constructs and job contentment differs based on the job setting and there exists correlation between openness to work experience and job satisfaction with some group of people such as co-workers and jobin-general in Job Description Index (JDI) and further (Judge et al., 2002) concluded that apart from the four facets in the five factor model of personality openness to experience was not significantly correlated with job satisfaction and even the moderators like cross-sectional and longitudinal research design was used in his meta-analysis, openness to experience was not significantly correlated.

\section{Agreeableness}

The facets of agreeableness traits are helpful, cooperative, caring and nurturing others, being affectionate. People who are high in this trait tend to exhibit positive experiences in social situations (Hayesa and Joseph, 2002). Agreeableness and its facet, honest were good predictors of friend satisfaction and other facet of agreeableness, obedience significantly predicted self-satisfaction (Esmaeili et al., 2013).

Agreeable individuals tend to exhibit and are more likely to experience happiness because they extremely love to have close interrelationships and those who are higher in this trait will have higher life satisfaction also (McCrae and Costa, 1991). (Judge et al., 1999) concluded that agreeableness trait is a good predictor of employees' performance of the jobs that requires teamwork and these findings are also supported by (Neuman and Wright, 1999).

\section{Conscientiousness}

Conscientiousness, best considered a combination of Achievement and Dependability, has a greater impact on behavior in situations where employees have extraordinary autonomy (Barrick and Mount, 1993). On the other end high Conscientiousness individual may lead to aggravating meticulousness, lack in direction and self-discipline, workaholic. "(Schneider, 1999), who studied the relationship between Conscientiousness and job satisfaction in various occupations, found significant relationships between them". (Maertz and Griffeth, 2004) has highlighted that persons who is having a tendency to quit the organization may ask themselves, "Do I have any responsibility for this organization which I won't be able to fulfill if I quit my job?", and if they possesses higher conscientiousness trait then they will stick on to the work place and they believe that some contractual commitment exists.

There is also evidence that each factor is associated with specific job family and occupation. Extraversion appears to be related to employees high sales performance, openness to experience predicts training to individuals and expatriate success, agreeableness is associated with performance in customer oriented and team-oriented jobs, neuroticism contributes to a wide range of jobs including management positions as well as jobs in the safety/security sector (Barrick et al., 2001; Mount et al., 1998; Vinchur et al., 1998).

\section{Impact of Big Five Personality on job satisfaction}

A Meta-analytic approach which depicts relationship between Five Factor (Big Five Model) and Job Satisfaction had predicted a good measure for each individual facets (-.29 for neuroticism, .25 for extraversion, .02 for Openness to Experience, .17 for Agreeableness and .26 for conscientiousness) and a multiple correlation measure of .41 with job satisfaction suggesting that individual's personality characteristics have a causal impact on job satisfaction (Judge et al., 2002) and has proved that the factor value of Extraversion and Conscientiousness has a positive correlation with job satisfaction and a negative one with Neuroticism, i.e. job satisfaction is higher in the case of higher Emotional Stability. Another study which relates three taxonomies (positive and negative affectivity, the Five-Factor model, and core self evaluations) to job satisfaction found that the three taxonomies were significantly related to job satisfaction (Judge et al., 2008). A Study which collected data from 500 employees of five major banks in Pakistan revealed that except neuroticism, all other facets of Big Five model showed significant positive correlation with job satisfaction and apart from that Age, Education, Salary and Marital Status have exhibited positive correlation with job satisfaction and women showed greater satisfaction level than men (Naz et al., 2013). In the context of an innovative software engineering job a study examined the incremental validity of proactive personality to predict overall job performance over the Big Five. Proactive Personality and the Big Five were measured in a sample of 243 engineers and 
overall job performance was assessed through supervisor ratings in a sub-sample of 95 of these engineers. Results showed that even though proactive personality represents a valid and important predictor of performance it does not show a relevant increment on the prediction yielded by extraversion, openness, conscientiousness, emotional stability and organizational tenure (Rodrigues and Rebelo, 2013).

Several researchers have acuminated out the correlation between the big five personality factors and job satisfaction. A research by (Judge et al., 2002)indicated that conscientiousness, extraversion, and agreeableness are positively correlated with job satisfaction, whereas neuroticism is negatively correlated with job satisfaction. Openness to experience has a trivial impact on job satisfaction. Conscientiousness, agreeableness, extraversion and neuroticism have most obvious connections with job satisfaction.

A research conducted by (Mhlanga, 2012) concluded that bank employees who are high in openness, conscientiousness and low in neuroticism tend to be more satisfied with their job. Agreeableness did not have a significant relationship with job satisfaction and employees with high levels of extraversion had negative significant correlation with job satisfaction. Overall, Big Five Personality model explained relatively small percentages in the variance of job satisfaction. This made him to conduct another study on individual facet (neuroticism) to determine its role in predicting job satisfaction. His research among bank employees declared that employees with lower level of neuroticism have higher levels of job satisfaction even though the levels of neuroticism were influenced by some demographic variables (Hlatywayo et al., 2013).

Therefore, the accumulated empirical evidence left no room for doubts concerning the relevancy of the Big Five personality dimensions as tools for predicting job satisfaction.

Apart from the acceptance and applicability of the five factor model for the prediction of job satisfaction and other important work related outcomes, some authors have alleged that the prediction of various determinants of behavior can be enhanced by adding some other personality constructs besides big five (Paunomen and Jackson, 2000). Accordingly Borman (2004) argued that "the rigid adherence to the big five model is probably not wise for our field" (p. 267). In addition to that, the criterion-related validity of personality traits might be appreciated if compound personality variables which are custom-made to the outcome (Viswesvaran et al., 2007).

In order to get a new valid measure for the variance of job satisfaction, positive psychological capital which has been described as "state-like" Positive Organization Behavior, or POB approach which motivates employees and infuse positivity which results in desirable work attitudes, performance and promotes high level of commitment over the employees.

The highlight of studies involving personality and job satisfaction is shown in Table 1.

\section{Positive Psychological capital (psycap) and its components}

By fusing positive psychology to the work place, (Luthans, 1999) has initiated the positive organization behavior research. It throws light on strengths rather than weaknesses and it lies beyond human and social capital. The exclusive feature of positive psychological behavior is that it is "state-like" and hence it can be developed and measured. This "state-like" and developable feature differentiates psycap constructs from "trait - like" constructs like Big-Five Personality, Core self-evaluations, positive and negative affectivity.

Psychological capital (psycap) is a higher order factor and a phenomenon in which positive psychological state of individuals is exhibited, and it is a representation of four component dimensions such as self-efficacy, optimism, hope, and resiliency (Luthans and Youssef, 2004; Luthans and Youssef, 2007; Luthans et al., 2008). Psycap appears to have a synergistic effect (i.e) the power of psycap as a whole is greater than its individual counterparts.

Luthans et al. (2007b: p. 3) define psychological capital as: "an individual's positive psychological state of development that is characterized by: (1) having confidence (self-efficacy) to take on and put in the necessary effort to succeed at challenging tasks; (2) making a positive attribution (optimism) about succeeding now and in the future; (3) persevering toward goals and, when necessary, redirecting paths to goals (hope) in order to succeed; and (4) when beset by problems and adversity, sustaining and bouncing back and even beyond (resiliency) to attain success".

Research reveals that psychological capital generally relates to performance (Avey et al., 2010; Rego et al., 2010; Walumbwa et al., 2010; Luthans et al., 2007a). When the performance of the employees increases, this will make them more positive and higher psychological resources to help them cope with challenges in the workplace. Also, when employees perform better, they will have self confidence and attribute more positively about their success now and in the future and their individual motivation will also increase as well. All of these will raise their psychological capital and employees with higher levels of psychological capital will also be more satisfied with their job (e.g. Luthans et al., 2007a).

\section{Impact of Positive psychological capital on job satisfaction}

A consensus gentium over the years and recent research findings have given a fulcrum to the importance of positivity in the work place. Disparate number of studies have assessed the importance of positive psychological capital in predicting work attitudes such as job satisfaction, and behaviors in the organization (Avey et al., 2010; Avey et al., 2011). Over the past decade, the field of organizational behavior has experienced a metamorphosis in thinking about positive psychological states that 
Table 1 Highlight of studies which concentrates on personality and job satisfaction

\begin{tabular}{|c|c|c|c|}
\hline Study & Subjects & Objectives & Findings \\
\hline $\begin{array}{l}\text { Tokar and Subich, } \\
1997\end{array}$ & Diversely employed Adults & $\begin{array}{l}\text { To determine whether Personality dimensions in } \\
\text { five-factor model predicts job satisfaction beyond } \\
\text { congruence }\end{array}$ & $\begin{array}{l}\text { Big five personality dimensions had contributed } \\
\text { greatly than congruence model in predicting job } \\
\text { satisfaction with extraversion and low neuroticism } \\
\text { as unique predictors. }\end{array}$ \\
\hline $\begin{array}{l}\text { Matzler and Renzel, } \\
2007\end{array}$ & Utility Sector employees & $\begin{array}{l}\text { To analyze personality traits as predictors of } \\
\text { employee satisfaction and its effect on affective } \\
\text { commitment. }\end{array}$ & $\begin{array}{c}20 \% \text { of the variance of employee satisfaction was } \\
\text { explained by personality traits. }\end{array}$ \\
\hline Julie Pozzebon, 2006 & $\begin{array}{l}\text { Men and Women in a } \\
\text { university setting }\end{array}$ & $\begin{array}{l}\text { To investigate the incremental validity of traits } \\
\text { and values in forecasting behaviour for self and } \\
\text { peer employees. }\end{array}$ & $\begin{array}{l}\text { The correlations between self and peer reports for } \\
\text { personality were high than values and behaviour } \\
\text { scales. Personality out predicted values. }\end{array}$ \\
\hline SuoHong Gang, 2008 & $\begin{array}{l}\text { Managers from a bank in } \\
\text { Beijing }\end{array}$ & $\begin{array}{l}\text { To scrutinize the relationship between Personality } \\
\text { traits and intrinsic career success (Job, career and } \\
\text { life satisfaction). }\end{array}$ & $\begin{array}{l}\text { Neuroticism and conscientiousness significantly } \\
\text { predicted job and career satisfaction. }\end{array}$ \\
\hline $\begin{array}{l}\text { Nina Adele Haddad, } \\
1989\end{array}$ & Staff nurses & $\begin{array}{c}\text { To examine the relationship between } \\
\text { demographic variables and personality factors } \\
\text { to nurses's job satisfaction and intention to stay. } \\
\text { This study uses CPI(California Psychological } \\
\text { Inventory) as a tool for personality. }\end{array}$ & $\begin{array}{l}\text { For predicting job satisfaction, Responsibility, } \\
\text { Achievement, Psychological mindedness and } \\
\text { socialisation from CPI scale were statistically } \\
\text { significant. }\end{array}$ \\
\hline $\begin{array}{l}\text { Rasch, H. R and } \\
\text { Harrell, A., } 1989\end{array}$ & $\begin{array}{l}\text { Management Advisory } \\
\text { Services(MAS) } \\
\text { Personnel }\end{array}$ & $\begin{array}{l}\text { To ascertain whether MAS Personnel possess } \\
\text { higher job satisfaction and voluntary turnover. }\end{array}$ & $\begin{array}{l}\text { MAS Personnel who possess high achievement } \\
\text { needs, Type A Personality and highly influential } \\
\text { tends to experience less work stress, greater job } \\
\text { satisfaction and low turnover. }\end{array}$ \\
\hline
\end{tabular}

makes an individual, a tremendous super power and to be an imperative asset to the organization.

Since psycap is developable, the psycap levels of individual can be enhanced through training interventions, a study which showed empirical evidence that training on these aspect not only enhance psycap levels but also enhances on-the-job performance (Luthans et al., 2010). A recent meta-analysis of 51 research samples showed significant relationships between psychological capital and employee attitudes such as job satisfaction, commitment and turnover intentions and employee behaviors such as citizenship behavior and job performance (Avey et al., 2011). Two studies conducted by (Luthans et al., 2007) analyzed how hope, optimism, resilience, efficacy individually and psycap as a whole predicted work performance and satisfaction. The results indicated that the single higher-order factor (psycap) may be a better predictor than individual facets. A study which analyzed the individual and team level psycap confessed that job satisfaction can be predicted by individual level psycap with the variance of $9.2 \%$ and results for turnover intentions revealed that $13 \%$ of variance was explained by individual level psycap only and in the core the effect of individual psycap on job satisfaction is greater when team psycap is high and reduced when team psycap is low (Martin et al., 2011).

A Study by (Bitmis and Ergeneli, 2013), analyzed the intervening effects of psychological capital and trust on the association between individual performance and job satisfaction and concluded that greater individual performance leads to greater psychological capital (Luthans et al., 2007, Walumbwa et al.,
2010, Rego et al., 2010) which in turn increases job satisfaction (Luthans et al., 2007).

A study by (Kaplan and Bickes, 2013) concluded that there exists no significant relationship between self-efficacy and hope sub-dimensions and job satisfaction and a positive and significant relationship exists between resiliency,optimism and job satisfaction. PsyCap may also act as a key to better understanding the perceived symptoms of stress, turnover intentions and job search behaviors (Avey et al., 2009). If employee's stress levels and turnover intentions have been identified then their job satisfaction level will get enhanced. Another research which analyses the importance of understanding person-organization fit, employee engagement, and job satisfaction through psycap revealed that psycap was a good predictor in understanding person-to-organization fit when leader's and employee's psycap levels are same (Larson et al., 2013).

Few studies have been highlighted in Table 2 which supports how psycap is contributing in finding out employee job satisfaction.

\section{Demographic impacts on job satisfaction}

Researchers have excavated a set of factors or variables that determine the job satisfaction level and plentiful amount of studies have been conducted on job satisfaction which scrutinizes the impact of demographic characteristics such as age, gender, designation, marital status, tenure and education. These factors are found critical in determining job satisfaction (Weidmer et al., 1998). 
Table 2 Highlights of few studies relating psychological capital and job satisfaction.

\begin{tabular}{cccc}
\hline Study & Subjects & Objectives & Findings \\
\hline $\begin{array}{c}\text { Larson and Luthans, } \\
2006\end{array}$ & Manufacturing Employees & To test the potential added value of & A significant relationship exists between \\
& & $\begin{array}{c}\text { psychological capital in predicting job } \\
\text { atisfaction and commitment. }\end{array}$ & organization commitment $(\mathrm{r}=.313)$. \\
\hline
\end{tabular}

Psycap is associated with job satisfaction and

it is a potential component in a HR Scorecard

Avey et al., 2009

Two samples from large financial firm
To scrutinize the relationship between psycap and performance. and it plays like a determinant factor for selecting and retaining candidates if their psycap score is high.

\begin{tabular}{|c|c|c|c|}
\hline $\begin{array}{l}\text { Bitmis and Ergeneli, } \\
2013\end{array}$ & Medical staff & $\begin{array}{l}\text { To analyze the mediating effects of psycap } \\
\text { and trust on individual performance and job } \\
\text { satisfaction relationship. }\end{array}$ & $\begin{array}{l}\text { Both psycap and trust acts as mediators for } \\
\text { the relationship between job satisfaction and } \\
\text { performance. }\end{array}$ \\
\hline Luthans et al., 2007 & $\begin{array}{l}\text { Management students(study1) and } \\
\text { employees in both service \&Hi-tech } \\
\text { manufacturing firms (study2) }\end{array}$ & $\begin{array}{l}\text { To examine how hope, optimism, resilience } \\
\text { and efficacy(psycap facets) and psycap } \\
\text { as a higher order construct predicts work } \\
\text { performance and satisfaction. }\end{array}$ & $\begin{array}{l}\text { Psycap as a higher order construct contributes } \\
\text { more in predicting employee's job } \\
\text { satisfaction than individual facet contribution. }\end{array}$ \\
\hline Larson et al., 2013 & Working Adults in U.S & $\begin{array}{l}\text { To examine whether employees and leaders } \\
\text { psycap level predicts person-organization fit, } \\
\text { engagement and job satisfaction }\end{array}$ & $\begin{array}{l}\text { The study earthed out the fact that if both } \\
\text { employees and leader psycap levels are } \\
\text { similar then assessing person-to-organization } \\
\text { fit might get enhanced. }\end{array}$ \\
\hline
\end{tabular}

The multifarious nature of employee's demographics changes job satisfaction due to the variations in perceptions and attitudes of employees belonging to different demographic groups (Khan et al., 2009).

Data have been collected by administering a questionnaire for evaluating job satisfaction among drivers and results revealed that the samples in 21-28 yrs old category showed higher job satisfaction levels than 29-39 yrs and above 40 yrs category and females exhibited higher job satisfaction levels than males and in turn males showed higher mean scores on emotional exhaustion and depersonalization and samples who had 1-4 years job tenure obtained higher mean score level in predicting job satisfaction than samples who had 5-8 yrs and 9-upper years and samples who had 9-upper years job tenure showed higher scores on emotional exhaustion than samples who had 1-4 yrs tenure period (Pourghaz et al., 2011).

Lin et al. (2007) showed there is a correlation between job satisfaction and age. According to (De Vaney and Chen, 2003) age has an effect on job satisfaction. Another research also revealed that satisfaction tends to increase towards middle age and marital status has not shown any relationship with job satisfaction (Guha, 1965).

\section{Combined effects of Big Five, Positive Psychological Capital and Demographic factors on Job Satisfaction}

A study which examined the incremental validity of psychological capital in predicting several important employee outcomes by suppressing the effects of big-five personality dimensions revealed that employee's psychological capital is related to their perceived performance, turnover intention, work happiness \& subjective well being, even after controlling for the Big Five Personality traits (Choi and Lee, 2014). The current study incorporates both

Another research aimed to delve into the relationships of coping strategies with Positive Psychological Capital and Big Five among undergraduate university students which concluded that positive psychological capital and big five were found to be significantly related to coping mechanisms except neuroticism, while high extraversion, openness \& conscientiousness individuals engaged in more problem-focused coping and finally concluded that personality factors and positive psychological capital has emerged as important constructs for detecting coping mechanisms (Khan et al., 2011).

\section{Conclusion}

It is concluded by analyzing various literatures that, few studies have investigated the impact of both big five, positive psychological for predicting individual outcome (Job Satisfaction). Most of the previous studies do not evaluate the combined effects (both psycap and big five) in predicting job satisfaction. Especially in banking sector, the examination of positive psychological capacities with Big Five Personality dimension and studying its impact on job satisfaction levels on employees is a unique dimension. It provides a robust step towards gauging the job satisfaction level and a better understanding of the 
relationships between Big Five, positive psychological capital, Demographic differences.

The present study aimed to contribute to this research topic by assessing the combined effects of both Big Five model and positive psychological capital model and whether psychological capital is exhibiting some incremental validity over big five on predicting job satisfaction levels.

\section{References}

Agho, A. O., Price, J. L., Mueller, C. W. (1993) Determinants of Employee Job Satisfaction: An Empirical Test of a Causal Model. Human Relations August. 46. pp. 1007-1027. DOI: 10.1177/001872679304600806

Ahmed, S., Uddin, M. N. (2012) Job Satisfaction of Bankers and its Impact in Banking: A Case Study of Janata Bank. ASA University Review. 6 (2).

Avey, J. B., Luthans, F., Youssef, C. M. (2010) The additive value of positive psychological capital in predicting work attitudes and behaviors. Journal of Management. 36 (2). pp. 430-452. DOI: 10.1177/0149206308329961

Avey, J. B., Nimnicht, J. L., Pigeon, N. G. (2009) Two field studies examining the association between psychological capital and employee performance. Leadership \& organizational development journal. 31 (5). pp. 384-401. DOI: 10.1108/01437731011056425

Avey, J. B., Reichard, R. J., Luthans, F., Mhatre, K. H. (2011) Meta-Analysis of the Impact of Positive Psychological Capital on Employee Attitudes, Behaviors, and Performance. Human Resource Development Quarterly. 22 (2). pp. 127-152. DOI: 10.1002/hrdq. 20070

Avey, J. B., Luthans, F., Jensen, S. M. (2009) Psychological Capital: A Positive Resource for Combating Employee Stress and Turnover. Human Resource Management. 48 (5). pp. 677-693. DOI: 10.1002/hrm.20294

Bakker, A. B., Van Der Zee, K. I., Lewig, K. A., Dollard, M. F. (2006) The relationship between the Big-Five personality factors and burnout : A study among volunteer counselors. The Journal of Social Psychology. 146 (1). pp. 31-50. DOI: 10.3200/socp.146.1.31-50

Barrick, M. R., Mount, M. K., Judge, T. A. (2001) Personality and Job Performance at the Beginning of the New Millennium: What Do We Know and Where Do We Go Next?. International Journal of Selection and Assessment. 9 (1-2). pp. 9-30. DOI: 10.1111/1468-2389.00160

Barrick, M. R., Mount, M. K. (1993) Autonomy as a moderator of the relationships between the Big Five personality dimensions and job performance. Journal of Applied Psychology. 78 (1). pp. 111-118. DOI: $10.1037 / / 0021-9010.78 .1 .111$

Borman, W. C. (2004) Introduction to the special issue: Personality and the prediction of job performance: More than the Big Five. Human Performance. 17 (3). pp. 267-269. DOI: 10.1207/s15327043hup1703_1

Chen, Z. H. (2013) The relationships among Job performance, personality, competence and customer loyalty - A case study of car salesperson. [Online] Available from: http://www.wseas.us/e-library/conferences/2013/Morioka/ISMA/ISMA-09.pdf [Accessed: 10th June 2014]

Choi, Y., Lee, D. (2014) Psychological capital, Big Five traits, and employee outcomes. Journal of Managerial Psychology. 29 (2). pp.122 - 140. DOI: 10.1108/JMP-06-2012-0193

Clark, L. A., Watson, D. (1991) General affective dispositions in physical and psychological health. In: Snyder, C. R., Forsyth, D. R. (eds.) Handbook of social and clinical psychology: The health perspective. New York: Pergamon.

Cohrs, C. J., Abele, A. E., Dette, D. E. (2006) Integrating Situational and Dispositional Determinants of Job Satisfaction: Findings From Three Samples of Professionals. The Journal of Psychology. 140 (4). pp. 363-395. DOI: $10.3200 / J R L P .140 .4 .363-395$
Connolly, J. J., Viswesvaran, C. (2000) The role of affectivity in job satisfaction: A meta-analysis. Personality and Individual Differences. 29 (2). pp. 265 281. DOI: 10.1016/s0191-8869(99)00192-0

Cropanzano, R., James, K., Konovsky, M. A. (1993) Dispositional affectivity as a predictor of work attitudes and job performance. Journal of Organizational Behaviour. 14 (6). pp. 595-606. DOI: 10.1002/job.4030140609

De Vaney, S. A., Chen, Z. (2003) Job satisfaction of recent graduates in financial services.Compensation and Working Conditions. [Online] Available from: http://www.bls.gov/opub/cwc/cm20030522ar01p1.htm [Accessed: 17th June 2014]

Digman, J. M. (1990) Personality structure: Emergence of the five-factor model. Annual Review of Psychology. 41 (1). pp. 417-440. DOI: 10.1146/annurev.ps.41.020190.002221

Digman, J. M. (1989) Five robust trait dimensions: Development, stability, and utility. Journal of Personality. 57 (2). pp. 195-214. DOI: 10.1111/j.1467-6494.1989.tb00480.x

Dormann, C., Fay, D., Zapf, D., Frese, M. (2006) A state-trait analysis of job satisfaction: On the effect of core self-evaluations. Applied Psychology. 55 (1). pp. 27-51. DOI: 10.1111/j.1464-0597.2006.00227.x

Esmaeili, B., Hosseini, H., Sadeghi, S., Pour, M. S., Rostami, H., Far, H. R. I. (2013) The Relationship between Neo Five-Big Personality Factors on Life Satisfaction in College Students. American Journal of Scientific Research. pp. 45-52.

Gelade, G. A., Dobson, P., Gilbert, P. (2006) National Differences in Organizational Commitment: Effect of Economy, Product of Personality, or Consequence of Culture. Journal of Cross-Cultural Psychology. 37 (5). pp. 542-556. DOI: 10.1177/0022022106290477

Goldberg, L. R. (1993) The structure of phenotypic personality traits: Authors' reactions to the six comments. American Psychologist. 48 (12). pp.13031304. DOI: 10.1037//0003-066x.48.12.1303

Bitmis, M. G., Ergineli, A. (2013) In The Role of Psychological Capital and Trust in Individual Performance and Job Satisfaction Relationship: A Test of Multiple Mediation Model. Procedia - Social and Behavioral Sciences. 99. pp. 173-179. DOI: 10.1016/j.sbspro.2013.10.483

Guha, T. N. (1965) Job Satisfaction among shoe-factory workers. Productivity. 6. pp. 89-94.

Haddad, N. A. (1989) Why nurses stay: The relationship of personality to job and career satisfaction. Proquest Dissertation. UMI number: 9017040.

Hampson, S. E., John, O. P., Goldberg, L. R. (1986) Category breadth and hierarchical structure in personality: Studies of asymmetries in judgments of trait implications. Journal of Personality and Social Psychology. 51 (1). pp. 37-54. DOI: 10.1037//0022-3514.51.1.37

Hayes, N., Joseph, S. (2002) Big 5 correlate of three measures of subjective well-being. Personality and Individual Differences. 34. pp. 723-727. DOI:10.1016/S0191-8869(02)00057-0

Hlatywayo, C. K., Mhlanga, T. S., Zingwe, T. (2013) Neuroticism as a Determinant of Job Satisfaction among Bank Employees. Mediterranean Journal of Social Sciences. 4 (13). pp. 549-554.

DOI: $10.5901 / \mathrm{mjss} .2013 . v 4 n 13 p 549$

Honggang, S. (2008) A Study On The Relationship Between Personality And Intrinsic Career Success: The Case Of Banking System In Beijing. Research Project.

Judge, T. A., Heller, D., Mount, M. K. (2002) Five-Factor Model of Personality and Job Satisfaction: A Meta-Analysis. Journal of Applied Psychology. 87. pp. 530-541. DOI: 10.1037/0021-9010.87.3.530

Judge, T. A., Bono, J. E. (2001) Relationship of core self-evaluations traits - self-esteem, generalized self-efficacy, locus of control and emotional stability- with job satisfaction and job performance: A meta-analysis. Journal of Applied Psychology. 86 (1). pp. 80-92. DOI: $10.1037 / / 0021-9010.86 .1 .80$ 
Judge, T. A., Locke, E. A., Durham, C. C., Kluger, A. N. (1998) Dispositional effects on job and life satisfaction: The role of core evaluations. Journal of Applied Psychology. 83 (1). pp. 17-34. DOI: 10.1037//0021-9010.83.1.17

Judge, T. A., Ilies, R. (2002) Relationship of personality to performance motivation: A meta-analytic review. Journal of Applied Psychology. 87 (4). pp. 797-807. DOI: 10.1037//0021-9010.87.4.797

Judge, T. A., Higgins, C. A., Thoresen, C. J., Barrick, M. R. (1999) The Big Five Personality Traits, General Mental Ability, and Career Success across the Life Span. Personnel Psychology. 52 (3). pp. 621-652 DOI: 10.1111/j.1744-6570.1999.tb00174.x

Judge, T. A., Heller, D., Klinger, R. (2008) The Dispositional Sources of Job Satisfaction: A Comparative Test. Applied Psychology: An International Review. 57 (3). pp. 361-372. DOI: 10.1111/j.1464-0597.2007.00318.x

Jang, K. L., Livesley, W. J., Vernon, P. A. (1996) Heritability of the big five personality dimensions and their facets: A twin study. Journal of personality. 64 (3). pp. 577-591. DOI: 10.1111/j.1467-6494.1996.tb00522.x

Kaplan, M., Bickes, D. M. (2013) The Relationship Between Psychological Capital and Job Satisfaction: A Study of Hotel Businesses in Nevsehir. [Online] Available from: http://www2.cbu.edu.tr/yonetimekonomi/ dergi/pdf/C20S22013/233-242.pdf [Accessed: 16th June 2014]

Khan, A. S., Khan, A. S., Khan, S., Nawaz, A., Khan, N. (2009) Demographic impacts on the Job-Satisfaction of the District Executive Officers in Local Government of NWFP Pakistan. Available from: http://www.gu.edu.pk/ New/GUJR/PDF/Dec-2009/9\%20Abdul\%20Sattar\%20Final\%20Paper. pdf [Accessed: 12th June 2014]

Khan, A., Siraj, S., Li, L. P. (2011) Role of Positive Psychological Strengths and Big five Personality Traits in Coping Mechanism of University Students. 2011 International Conference on Humanities, Society and Culture IPEDR.

Koltai, T., Kalló, N. (2010) Increasing Customer Satisfaction in Queuing Systems with Rapid Modelling. In: G. Reiner (ed.) Rapid Modelling and Quick Response. Springer London. pp. 119-130.

DOI: 10.1007/978-1-84996-525-5_9

Larson, M., Luthans, F. (2006) Potential added value of Psychological capital in predicting work attitudes. Journal of Leadership and organizational studies. 13 (1). pp. 45-62. DOI: 10.1177/10717919070130010701

Larson, M. D., Norman, S. M., Hughes, L. W., Avey, J. B. (2013) Psychological Capital: A New Lens for Understanding Employee Fit and Attitutes. International Journal of Leadership Studies. 8 (1). pp. 28-43.

Lin, M-C., Li, I., Lin, K. (2007) The relationship between personal traits and job satisfaction among Taiwanese community health volunteers. Journal of Clinical Nursing. 16 (6). pp. 1061-1067. DOI: $10.1111 / \mathrm{j} .1365-2702.2005 .01502 . x$

Luthans, F. (1999) Origins of POB: The Positive Psychology Movement. [Online] Available from: http://en.wikipedia.org/wiki/Positive_organizational_behavior. [Accessed: 19th June 2014]

Luthans, F., Youssef, C. M. (2004) Human, Social and now positive psychological capital management: Investing in people for competitive advantage. Organizational Dynamics. 33 (2). pp. 143-160. DOI: 10.1016/j.orgdyn.2004.01.003

Luthans, F., Youssef, C. M. (2007) Emerging Positive Organizational Behavior. Journal of Management. 33 (3). pp. 321-349. DOI: $10.1177 / 0149206307300814$

Luthans, F., Norman, S. M., Avolio, B. J., Avey, J. B. (2008) The mediating role of psychological capital in the supportive organizational climate employee performance relationship. Journal of Organizational Behavior. 29 (2). pp. 219-238. DOI: 10.1002/job.507

Luthans, F., Avolio, B. J., Avey, J. B., Norman, S. M. (2007a) Positive Psychological Capital: Measurement and Relationship with Performance and Satisfaction. Personnel Psychology. 60 (3). pp. 541-572. DOI: $10.1111 /$ j.1744-6570.2007.00083.x
Luthans, F., Youssef, C. M., Avolio, B. J. (2007b) Psychological Capital, Developing the Human Competitive Edge. Oxford: Oxford University Press.

Luthans, F., Avolio, B. J., Avey, J. B., Norman, S. M. (2007) Positive Psychological Capital: Measurement and Relationship with Performance and Satisfaction. Leadership Institute Faculty Publications. Paper 11 retrieved from: http://digitalcommons.unl.edu/leadershipfacpub/11

Luthans, F., Avey, J. B., Avolio, B. J., Peterson, S. J. (2010) The development and resulting performance impact of positive psychological capital. Human Resource Development Quarterly. 21 (1). pp. 41-67. DOI: $10.1002 / \mathrm{hrdq} .20034$

Maertz, C. P. Jr., Griffeth, R. W. (2004) Eight Motivational Forces and Voluntary Turnover:A Theoretical Synthesis with Implications for Research. Journal of Management. 30 (5). pp. 667-683. DOI: 10.1016/j.jm.2004.04.001

Matzler, K., Renzl, B. (2007) Personality traits, Employee satisfaction and Affective Commitment. Total Quality Management. 18 (5). pp. 589-598. DOI: 10.1080/14783360601061528

Martin, A., O’Donohue, W., Dawkins, S. (2011) Psychological Capital at the individual and team level: Implications for job satisfaction and turnover intentions of emergency services volunteers. Proceedings of the 2011 ANZAM Conference. 6th-9th December 2011. Wellington. pp. 1-17.

McCrae, R. R., Costa, P. T. Jr. (1991) The NEO Personality Inventory: Using the five-factor model in counseling. Journal of Counseling and Development. 69 (4). pp. 367-372. DOI: 10.1002/j.1556-6676.1991.tb01524.x

McCrae, R. R., Costa, P. T. Jr. (1996) Toward a new generation of personality theories: Theoretical contexts for the five-factor model. In: Wiggins, J.S. (ed.): The five-factor model of personality: Theoretical perspectives. New York: Guilford.

Medlin, B. (2010) Bella's: a case study in organizational behaviour. Journal of Business Cases \& Applications. 4. p. 1-11.

Mhlanga, T. S. (2012) An investigation into the relationship between certain personality traits and job satisfaction. A case of selected bank employees in the eastern cape province. Master Thesis. University of Fort Hare.

Mount, M. K., Barrick, M. R., Stewart, G. L. (1998) Five-factor model of personality and performance in jobs involving interpersonal interactions. Human Performance. 11 (2-3). pp. 145-165. DOI: $10.1080 / 08959285.1998 .9668029$

Naz, S. , Rehman, S., Saqib, H. (2013) The Relationship between Job Satisfaction and Personality trait among Bank employees. Far East Journal of Psychology and Business. 11 (3). pp. 57-72.

Neuman, G. A., Wright, J. (1999) Team effectiveness: beyond skills and cognitive ability. Journal of Applied Psychology. 84 (3). pp. 376-89. DOI: $10.1037 / / 0021-9010.84 .3 .376$

Paunonen, S. V. (1993) Sense, nonsense, and the Big Five factors of personality. Paper presented at the 101st Annual Convention of the American Psychological Association. Canada: Toronto, Ontario.

Paunonen, S. V., Jackson, D. N. (2000) What is beyond the Big Five? Plenty! Journal of Personality. 68 (5). pp. 821-835.

DOI: 10.1111/1467-6494.00117

Pourghaz, A. W., Tamini, B. H., Karamad, A. (2011) Do Demographic Characteristics Make a Difference to Job Satisfaction, Organizational Commitment and Burnout among Travel Agency Drivers? Journal of Basic and Applied Scientific Research. 1 (8). pp. 916-923.

Pozzebon, J. (2006) Personality traits and Personal Values: An investigation into the importance of each in the prediction of behavior. Master thesis, Department of Psychology, Brock University.

Ramachandran, A., Chidambaram, V. (2012) A review of customer satisfaction towards service quality of banking sector. Periodica Polytechnica Social and Management Sciences. 20 (2). pp. 71-79.

DOI: $10.3311 /$ pp.so.2012-2.02 
Rasch, H. R., Harrell, A. (1989) The Impact of Individual Differences on MAS Personnel Satisfaction and Turnover Intentions. Journal of information systems.

Rego, A., Marques, C., Leal, S., Sousa, F., Pina e Cunha, M. (2010) Psychological capital and performance of Portuguese civil servants: exploring neutralizers in the context of an appraisal system. The International Journal of Human Resource Management. 21 (9). pp. 1531-1552. DOI: $10.1080 / 09585192.2010 .488459$

Rodrigues, N., Rebelo, T. (2013) Incremental validity of proactive personality over the Big Five for predicting job performance of software engineers in an innovative context. Journal of Work and Organizational Psychology. 29 (1). pp. 21-27. DOI: 10.5093/tr2013a4

Salgado, F. J. (2005) Personality and Social Desirability in Organizational Settings: Practical implications for Work and Organizational Psychology. Papeles del Psicólogo. 26. pp. 115-128.

Sarwar, S., Abugre, J. (2013) The Influence of Rewards and Job Satisfaction on Employees in the Service Industry. The Business \& Management Review, 3 (2). pp. 22-32.

Schnedier, M. H. (1999) The relationship of personality and job settings to job satisfaction. Dissertation Abstracts International: Section B: Science and Engineering. 59. 6103.

Tanoff, G. F. (1999) Job satisfaction and personality: The utility of the fivefactor model of personality. Dissertation Abstracts International: Section B: The Sciences and Engineering. 60. 1904.

Thoresen, C. J., Kaplan, S. A., Barsky, A. P., Warren, C. R., de Chermont, K. (2003) The affective underpinnings of job perceptions and attitudes: A meta-analytic review and integration. Psychological Bulletin. 129 (6). pp. 914-945. DOI: 10.1037/0033-2909.129.6.914
Tokar, D. M., Subich, L. M. (1997) Relative contribution of congruence and personality dimensions to job satisfaction. Journal of Vocational Behavior. 50 (3). pp.482-491.

Vinchur, A. J., Schippmann, J. S., Switzer III, F. S., Roth, P. L. (1998) A metaanalytic review of predictors of job performance for sales people. Journal of Applied Psychology. 83 (4). pp. 586-597.

DOI: 10.1037//0021-9010.83.4.586

Vijayabanu, C., Amudha, R. (2012) A study on efficacy of employee training: Review of literature. Business: Theory and Practice. 13 (3). pp. 275-282. DOI: $10.3846 /$ btp.2012.29

Vijayabanu, C., Amudha, R., Surulivel, S. T. (2013) A study on efficacy of induction training programme in Indian Railways using factor analysis. Business: Theory and Practice. 14 (2). pp. 140-146. DOI: $10.3846 /$ btp.2013.15

Vijayabanu, C., Therasa, C. (2014) Training based on sequential need analysis process in a public sector organization. International Journal of Industrial Engineering and Management. 5 (3). pp. 139-150.

Viswesvaran, C., Deller, J., Ones, D. S. (2007) Personality Measures in Personnel Selection: Some new contributions. International Journal of Selection and Assessment. 15 (3). pp. 354-358. DOI: $10.1111 / j .1468-2389.2007 .00394 . x$

Walumbwa, F. O., Peterson, S. J., Avolio, B. J., Hartnell, C. A. (2010) An investigation of the relationships among leader and follower psychological capital, service climate, and job performance. Personnel Psychology. 63 (4). pp. 937-963. DOI: 10.1111/j.1744-6570.2010.01193.x

Wiedmer, M. S. (1998) An Examination of factors affecting employee satisfaction. Department of Psychology, Missouri Western State University Publications, USA. 